\title{
13 Advanced producer servicing networks of world cities
}

Peter J. Taylor, Ben Derudder, Michael Hoyler and Frank Witlox

\section{Introduction}

In Chapter 6 advanced producer services featured crucially in the exposition of the interlocking network model. Drawing on Sassen's (1991) identification of this work as integral to global city formation, the office networks of advanced producer service firms were modelled to generate a world city network. To this end the office networks were aggregated so that differences between different service sectors were lost in the initial modelling. But advanced producer services are of interest in their own right and not just as input in world city network analysis. In this chapter the service categories are 'recovered' and described for their importance in contemporary globalization processes.

The rise of the service sector was one of the most remarkable changes in the twentieth century world economy (Bryson and Daniels, 1998). Industries in this sector can be divided into those servicing individuals and households (e. g. retail firms) and those servicing businesses (e.g. advertising agencies). These are commonly referred to as consumer services and producer services respectively although in practice the distinction is often blurred. For instance, most bank branches in cities offer both retail banking for their individual customers, and specific financial services for their business customers. Nevertheless this distinction is a useful one because the business services developed in new ways in the last decades of the twentieth century to create a crucial knowledge component of economic globalization. These were very high value-added services through specialized knowledges - professional, creative and financial - that are the advanced producer services, the subject of this chapter. 


\section{Why advanced producer services are important}

As noted in Chapter 6, advanced producer service firms followed their clients from the 1980s onwards to create worldwide office networks. It is worth pondering this astonishing turnaround in the scale of their activities. Service firms have traditionally been very local because they built up the client base through face-to-face encounters. The result was that firms became designated by their city location - a Washington law firm, a Paris advertising agency, a London bank, etc. But with worldwide offices to service global client bases this simple process has been superseded. With the combining of the computer and communications industries in the 1970s, plus vastly expanded business air travel, the situation has become much more complicated reflected in new global geographies of servicing. Thus when scholars refer to a new information age and network society (e.g. Castells, 1996), it is advanced producer service firms that are the archetypal generators of this new world. And yet, the city origins do not disappear. Despite globalization, the business culture of firms while becoming more cosmopolitan also remains local and national (Dicken, 2007): for instance, London and New York law firms remain very different even though their work entwines through both cities and beyond as clearly illustrated by Faulconbridge (2007). It is this 'glocalization' that makes advanced producer service firms so theoretically interesting for understanding contemporary globalization.

But there are also three related practical reasons why these firms demand special attention. First, advanced producer services can be reasonably interpreted as a contemporary 'indicator sector' in the world economy. That is to say, places where this sector is expanding indicate economic success. Thus although firms from this sector, except for banks, remain relatively small compared to other economic sectors - they hardly get a mention in the Forbes 2000 top corporations - their importance lies not in their size but in their relationality. These firms instigate and thrive through their centrality in economic webs that constitute cities and their networks. Just like the vitality of ecologies can be monitored via 'indicator species,' so too 
can city-economies via indicator sectors, and in economic globalization advanced producer services are arguably the best candidate for this role.

Second, and again size notwithstanding, advanced producer service firms are at the cutting edge of contemporary modern economy. As traditional 'knowledge industries', firms in this sector were well placed to take advantage of the rise of Castells' (1996) informational society. Like a limited number of other sectors, notably logistics, these firms have enthusiastically taken up the economic openings made possible by new electronic communication. In this way they have been at the forefront of exploiting the network society to generate worldwide work practices, the cutting edge of economic change over recent decades.

Third, in their worldwide work practices, advanced producer service firms have had a crucial role in enabling economic globalization. This enabling is usually allocated to Castell's (1996) bottom layer of his global space of flows - electronic and transport infrastructure - and there has been a literature that claimed an 'end of geography' in a 'borderless world' (Brown, 1973; O'Brien, 1991; Ohmae, 1999). We know now that this is not how globalization has operated; places are still important and borders remain. Corporations manoeuvre through globalization by using the specialist expert knowledge of advanced producer service firms operating through the real social relations that are Castells' second tier in his spaces of flows. It is here that contemporary globalization has been made a viable means of production and consumption.

The latter point can be further developed by briefly considering some core functions of the five sub-groups of service firms focused on in Chapter 6. We treat them in an order that traces their distinctive contributions.

1. Advertising firms were critical to the construction of consumer modernity, ultimately providing contemporary globalization with its essential nature (Taylor, 2008). They emerged in the early twentieth century to convert wants into needs in the birthplace of modern consumerism, the USA. The work diffused to other 'affluent societies' in western Europe and Japan in mid-century, before globalizing in the last decades of the 
twentieth century. The final move enabled needs to be converted to wants globally to provide the beginnings of a worldwide demand side to contemporary globalization, its crucial component that distinguishes it from earlier production-only globalizations.

2. For corporations to provide for global consumer demand it would be nice to operate in a borderless world and a key role of global law firms is to help get as close as possible to this ideal. Through their expertise in inter-jurisdictional law practices they ensure business can proceed smoothly in a transnational manner. Anchoring other national law systems to either English common law (initially through London) or New York State law (initially through New York City) in order to translate across myriad jurisdictions, law firms help take the borders out of business.

3. Ultimately it is all about the bottom line, finance. Financial services firms have been some of the most creative within economic globalization through inventing new financial instruments to move, change and expand capital as never before. This was the role they successfully played until 2008. As traditional merchant banks morphed into contemporary investment banks, international financial centres - not least London and New York - generated global financial movements far outpacing traditional international trade in the world economy. It is this 'financial globalization' that some see as contemporary globalization's real nature (Arrighi, 1994).

4. And through all this economic growth, it was accountancy firms that expanded the most. Their key role relates to their core competency in auditing. This might not sound very exciting but as globalization brought in firms from outside the core regions of the world economy it generated new forms of firms including relatively 'informal' family corporations. In a world where amalgamations and takeovers are commonplace, it is necessary that all firms conform to similar standards of auditing. This is what accountancy firms provide - they were especially active in the late 1990s economic turndown in Asia where their intervention enabled failing local firms to be scooped up by western corporations. 
5. Management consultancy is the new kid on the block, a late twentieth century boom industry built on the back of hundreds of thousands of MBA graduates coming onto the global labour market. Management consultants advise corporations on enhancing the bottom line through savings via reorganizations; effectively this has meant redeploying labour with the middle rung of management being a favourite target. Their key role is to create a more homogeneous corporate world by bringing all firms down to a common level in labour costs.

These groups of services vary in their relation to cycles in the world economy: in the good times advertising and financial firms tend to prosper, more challenging times are better for law and accountancy firms. Management consultancy work is never done.

\section{Five new service geographies in globalization}

In this section we look at the new geographies of servicing in globalization using the 2008 data and analysis from Chapter 6 broken down into the five groups of services. Thus the analyses below are based upon the original services value matrix of 525 cities x 175 firms where a service value (ranging from 0 to 5) indicates the use of a city by a firm. The 175 firms consist of 75 financial service firms and 25 each of accountancy, advertising, law and management consultancy firms. For a detailed description see Taylor et al. (2011).

Each group is analyzed separately to produce network connectivities for the cities. These values (ranging from 0 to 1 ) indicate the degree of integration of a city into the specific networks: how well Washington DC is into integrated into law networks; how well Paris is integrated into advertising networks, and so on. All values are given as proportions of the highest connectivity for each group of firms. In the discussion below we consider only the leading cities in the sector networks: those with at least one half of the highest connectivity (i.e. the network connectivity values reported are 0.5 and above). It is these values that define the 
city geographies described below. They are presented in the order in which the groups of firms were treated above.

Advertising: New York imperium

It is no surprise that New York dominates the advertising city network (Table 13.1); originally clustered in Madison Avenue, this advanced producer service remains the archetypal American industry maintaining its tradition centre. It is from this locale that first national advertising campaigns and latterly global advertising campaigns were devised and practised through networks of "subsidiary' cities. However moving on the global stage meant confronting new levels of national, language and cultural differences across the world that have required additional local inputs to customize the product. This is reflected in the large number and worldwide range of cities that are integrated into the advertising city network in Table 13.1.

[PLEASE INSERT TABLE 13.1 HERE]

Most advertising is still based upon TV campaigns. Television remains largely a national medium; stations transmit to a 'national audience' within their state's boundaries. Thus a 'global' campaign has to be, in reality, an 'international' campaign with a state by state practice. Thus the 37 important advertising cities below New York in Table 13.1 are from 33 different countries. These cities are the main TV centres for the larger national markets across the world. Usually that city is the capital city but there are also cases where the capital is not the economic and cultural centre of the country: Sydney, Mumbai, Toronto, Istanbul and Jeddah are each non-capital TV centres. There are just three countries with multiple cities in Table 13.1. The special case of China where Hong Kong, Shanghai and Beijing are important advertising cities is partly a size effect but also reflects the triple-city centred nature of China's recent 
economic rise (Lai, 2009). The second example is Italy where both Milan and Rome are advertising cities; sharing a large to medium national market means that the two cities are relatively lowly ranked.

It is important that omissions from Table 13.1 are also mentioned. The whole of Africa is off the network map; largely a feature of the small size of national markets. But there are large markets not represented. The most obvious case is the USA itself; despite this industry's American origins, after New York only Chicago features, but ranked a lowly 35, and no other important advertising cities are found. And there are two very important national markets missing altogether; Germany and Brazil which both have relatively 'flat' urban 'hierarchies'. Germany has four main cities servicing its large economy for advertising: Frankfurt, Düsseldorf, Hamburg and Berlin; and Brazil has two: Sao Paulo and Rio de Janeiro. These examples may indicate more than dividing national markets. The New York 'imperial mode' of advertising was first challenged in the US national market and Faulconbridge et al. (2011) argue that this may well now be happening globally. New York remains the main centre for advertising in the world but other centres are now emerging, some still strongly linked to New York and others more independent. For further discussion of the globalization of advertising see Taylor (2008) and Faulconbridge et al. (2011).

Law: NYLON duopoly

Law is similar to advertising in having a basic international framework for its practice: every country has its own distinctive legal and associated professional certification for practice. But this internationality is not reflected in cities integrated into global law networks. Legal services have very different global geography from advertising (Table 13.2). By the definition used here, there were only eight global law cities in 2008. And these were dominated by the duopoly of London and New York. It was in these two cities that law firms developed the expertise for 
inter-jurisdictional practices, which is still reflected in the use of two basic legal frameworks (as noted previously, English common law and New York state law).

[PLEASE INSERT TABLE 13.2 HERE]

Beyond the duopoly, the next four ranked law cities are also from North West Europe and the USA: Paris and Washington are major national capitals, and Frankfurt and Brussels are major European Union centres for finance and politics respectively. The top six ranked cities confirm the close affinity of leading law firms and their banking and government clients.

The only breakout of the traditional 'North Atlantic' core relates to the opening up of European COMECON and Communist China in the late twentieth century. In both cases the nature and policies of the previous regimes meant there was a commercial law vacuum that London and New York law firms were more than willing to fill. Hong Kong became the 'global legal gateway' to the new commercial China, and Moscow attracted law firms because it was the capital of the country that had the largest turnover in property in COMECON consequent upon the privatization of state assets.

The lesson of this geography of globalization is that networks do not have to be 'horizontal' in nature to facilitate globalization. Since there is no suggestion that this highly restricted geography has limited legal worldwide competence, this case illustrates a global projection of power through extraordinary high value-added work.

Financial services: global trinity

In twenty-four hour financial markets, there need to be three time-zoned centres for continuous expert attention and capabilities. This was originally provided for by Tokyo, London and New York (Thrift, 1989), Sassen's (1991) initial 'global cities', but since 1990 the stagnation of the 
Japanese economy and the massive growth of the Chinese economy have meant that Hong Kong has replaced Tokyo. Tokyo was always the 'poor relation' of the first 'big three' (Sassen, 1999) but this does not seem to be the case with Hong Kong. Table 13.3 shows London, New York and Hong Kong almost equally integrated into financial services city networks. This is now a tight global financial trinity at the heart of economic globalization.

\section{[PLEASE INSERT TABLE 13.3 HERE]}

But this city network is not part of a sequence-continuality from single (advertising) to dual (law) to triple dominance. Unlike Tables 13.1 and 13.2, Table 13.3 records numerous cities with network integration levels above 0.75 ; in fact this defines the top eight. And what a curious top eight it is: apart from the top two and Paris ranked 6th, all these highly integrated financial centres are in the western Pacific Rim: Tokyo, of course, now in 4th place, but also Singapore, Shanghai and Sydney recording network connectivities above 0.75. The Pacific Asia has long been identified as the world region with concentration of financial services (Taylor, 2004), but this has been remarkably accentuated through to 2008. More recent evidence suggests the 2008 financial crisis has further augmented this trend (Derudder et al., 2010a). In addition, Seoul (9th), Beijing (12th), Taipei (13th), Kuala Lumpur (20th), Jakarta (24th) and Bangkok (26th) show further financial power in this region.

But there is more to this global geography than the Pacific Asian cluster. There are 28 cities listed in Table 13.3 and most of the remainder are European (11 to be precise), plus Toronto and one Indian city, Mumbai, and two Latin American cities, Sao Paulo and Buenos Aires.

However, perhaps the noteworthy feature of Table 13.3 is to be found in an omission: there is only one other US city - Chicago (21st) - found to be strongly integrated into financial services city networks. This does not mean that the USA has no other major financial centres 
outside New York but they do not feature large in the city networks of financial services firms. This dearth of US cities with high network connectivities is a common feature in world city analyses - for further discussion see Taylor and Lang (2005), Derudder et al. (2010b), Hanssens et al. (2010) and Taylor et al. (2011).

\section{Accountancy: ubiquitous globalization}

The first point to make about the global geography of accountancy is that there are 45 cities listed in Table 13.4. Accountancy firms (and associations of such firms) tend to have much larger office networks than any other advanced producer service and this leads to the surfeit of global accountancy cities.

\section{[PLEASE INSERT TABLE 13.4 HERE]}

Apart from the top three ranking cities being very familiar from other tables - London, New York and Hong Kong - Table 13.4 displays a rather distinctive geography. For instance, Buenos Aires (9th) is ranked above Tokyo (13th), and Tel Aviv (12th) and Auckland (18th) are ranked above Seoul (19th). But this does not indicate a diminution of Pacific Asian representation in global accountancy cities: there are four cities from the region ranked above Tokyo, including Beijing (8th) and Kuala Lumpur (10th). And the surprises do not end here. There are 17 European cities appearing as strongly integrated into this network, four of which appear in these analyses for the first time: Berlin (25th), Oslo (29th), Barcelona (33rd), and Hamburg (44th). Similarly there are new Latin American cities appearing: three - Bogota (32nd), Santiago (36th) and Guadalajara (39th) - out of seven cities from this world region in all. The Middle East is represented, not by Dubai, but by Kuwait (31st), Jeddah (35th) and Riyadh (40th). And finally there is African representation: Johannesburg (41st). Again there is 
only one US city included in addition to New York: Chicago (43rd). This is the most worldwide of all advanced producer service networks, and is very different from the advertising network which has the second highest number of major integrated cities (Table 13.1). The unexpected in the geography of global accountancy cities suggests a fairly random distribution.

The only process that can be discerned from the list is that it includes cities that have required additional audit capacity to enable increased foreign direct investment. The role of Buenos Aires in the recovery of Argentina's economy after its financial crisis in 2001-2 might account for this city's particularly surprising ranking in Table 13.4. A similar story concerning the South East Asian financial crisis of 1997-8 might account for the relatively high rankings of Kuala Lumpur and Jakarta. But overall what is being shown here is the ubiquity of accountancy in the contemporary world economy: this service has been the big winner of globalization.

\section{Management Consultancy}

To some extent global management consultancy was born out of accountancy: some of the major firms are the result of dividing off from accountancy firms because of potential conflicts of interest between auditing and consultancy. But the geography of their service networks could hardly be more different: Table 13.5 lists the second fewest cities.

[PLEASE INSERT TABLE 13.5 HERE]

Like advertising, management consultancy's main origins are in the USA and in Table 13.5 New York is very dominant. Furthermore, two other US cities appear as strongly integrated into this service network: Chicago (4th) and Atlanta (12th). Otherwise the global consultancy cities are all to be found in Western Europe and Pacific Asia with the sole exception of Mumbai (11th). 
There are two interpretations of this service geography. First, management consultancy is concentrated in few regions in the world because it is in these places that its work is most needed: down-sizing by stripping out middle management. However, it must be remembered that what we are dealing with are processes and 2008 results are just a cross-section. Second, therefore, management consultancy is a relatively new global service and its contemporary concentration just reflects early days before branching out into new horizons.

\section{Conclusion: globalizing effects of networks}

The key finding of this chapter is that there are very different geographies of globalization even within just one major economic sector, advanced producer services. In this short conclusion these differences will be compared by treating each network geography as representing a process and then measuring its geographical effect.

The notion of globalization replaced an earlier conceptualization of the world divided into three: a rich 'first world', a communist 'second world', and a poor 'third world'. Although an unsatisfactory taxonomy given very different criteria for differentiations, it became the 'common sense' description of the world until the end of the Cold War in 1989-91 and the consequent demise of communism as a major political force. This eliminated the 'second world' and left the idea of 'third world' in somewhat of a limbo, which was 'solved' by Western triumphalism proclaiming the birth of 'one world'. Globalization came to be the label that confirmed the new world order. This timing is interesting because it is in the period after 1990 that advanced producer services really began to expand rapidly in cities across the world to create the networks studied in this chapter. Therefore the 'one world' thesis can be assessed through looking at how each of the erstwhile divisions has fared in contemporary globalization.

In Table 13.6 the major cities integrated into each of the five service networks are distributed across the earlier triplicate categories. The first world includes northern America (Canada and USA), Western Europe (non-communist countries) and parts of Pacific Asia 
(Japan, South Korea, Taiwan, Hong Kong and Singapore); the second world includes all communist states before 1989; and the third world includes the three 'continents' - Latin America, Africa and Asia - not including 'first world Pacific Asia' and communist states. The second column in Table 13.6 shows the variation in numbers of major cities in each network; the remaining columns show percentages of cities in each of the initial 'three worlds'.

\section{[PLEASE INSERT TABLE 13.6 HERE]}

The first point to make is that all cells are above zero except one showing that major cities strongly integrated into service networks are found in all three worlds with the sole case of legal services not represented in the erstwhile 'third world'. Global law is the most concentrated of networks and therefore this is perhaps not a surprise. On the other hand, again not surprisingly, it is the old 'first world' that has by far the most major network cities, always more than half, in all five services. However there is a separation of service networks in terms of degree of 'first world' continued dominance: three networks have less than two-thirds of their major network cities in this category (advertising, financial services and accountancy), and for the other two (law and management consultancy) over $80 \%$ of major cities are in the old 'first world'. This simple dichotomy directly reflects the total number of major network cities in the different services: the basic globalizing effect is that the more network concentration in cities, the less network diffusion across the world.

The conclusion is that while legal services and management consultancy are sorting out global capital in the richer countries, accountancy is spearheading globalizing effects through getting other regions fit for investment, advertising is expanding the global market resulting in financial services deploying and expanding capital across the world. This was the world in 2008 since when the financial and economic crises may indicate further global effects consequent 
upon the rise of BRIC (Brazil, Russia, India and China), two erstwhile 'third world states' and two former 'second world states'.

\section{References}

Arrighi, G. (1994), The Long Twentieth Century, London: Verso.

Brown, L.R. (1973), World without Borders, New York: Vintage.

Bryson, J. and Daniels, P.W. (eds) (1998), Service Industries in the Global Economy, Cheltenham: Edward Elgar.

Castells, M. (1996), The Rise of the Network Society, Oxford: Blackwell.

Dicken, P. (2007), Global Shift, New York: Guilford Press, 5th edition.

Derudder, B., M. Hoyler and P.J. Taylor (2010a), 'Goodbye Reykjavik: International banking centres and the global financial crisis', Area, doi: 10.1111/j.1475-4762.2010.00968.x

Derudder, B., P.J. Taylor, P. Ni, A. De Vos, M. Hoyler, H. Hanssens, D. Bassens, J. Huang, F. Witlox, W. Shen and X. Yang (2010b), 'Pathways of change: shifting connectivities in the world city network, 2000-08', Urban Studies, 47 (9), 1861-1877.

Faulconbridge, J. (2007), 'Relational networks of knowledge production in transnational law firms', Geoforum, 38 (5), 925-940.

Faulconbridge, J.R., J.V. Beaverstock, C. Nativel and P.J. Taylor (2011), The Globalization of Advertising: Agencies, Cities and Spaces of Creativity, London: Routledge.

Hanssens, H., B. Derudder, P.J. Taylor, M. Hoyler, P. Ni, J. Huang, X. Yang and F. Witlox (2010) 'The changing geography of globalized service provision, 2000-2008', The Service Industries Journal, doi: 10.1080/02642069.2010.503887

Lai, K.P.Y. (2009), 'Global cities in competition? A qualitative analysis of Shanghai, Beijing and Hong Kong as financial centres', GaWC Research Bulletin, 313, available at www.lboro.ac.uk/gawc/rb/rb313.html (accessed 20 September 2010). 
O’Brien, R. (1991), Global Financial Integration: The End of Geography, London: Thomson Learning.

Ohmae. K. (1999), The Borderless World, New York: Harper.

Sassen, S. (1991), The Global City, Princeton, NJ: Princeton University Press.

Sassen, S. (1999), ‘Global financial centers’, Foreign Affairs, 78 (1), 75-87.

Taylor, P.J. (2004), World City Network, London: Routledge.

Taylor, P.J. (2008) 'Advertising and cities: a relational geography of globalization in the early twenty first century', in E. Kofman and G. Youngs (eds), Globalization: Theory and Practice, New York: Continuum, 3rd edition, pp. 205-220.

Taylor, P.J. (2011), ‘Advanced producer services in the world economy', in P. J. Taylor, P. Ni, B. Derudder, M. Hoyler, J. Huang and F. Witlox (eds), Global Urban Analysis: A Survey of Cities in Globalization, London: Earthscan, pp. 32-39.

Taylor, P.J. and R.E. Lang (2005), U.S. Cities in the 'World City Network', Washington, DC: The Brookings Institution (Metropolitan Policy Program, Survey Series).

Taylor, P.J., P. Ni, B. Derudder, M. Hoyler, J. Huang and F. Witlox (eds) (2011), Global Urban Analysis: A Survey of Cities in Globalization, London: Earthscan.

Thrift, N. (1989), 'A hyperactive world', in R.J. Johnston, P.J. Taylor and M.J. Watts (eds), Geographies of Global Change, Oxford: Blackwell, pp. 18-35. 
Table 13.1 Advertising network connectivity

\begin{tabular}{|c|c|c|}
\hline Rank & City & NC \\
\hline 1 & New York & 1.00 \\
\hline 2 & London & 0.75 \\
\hline 3 & Paris & 0.75 \\
\hline 4 & Hong Kong & 0.73 \\
\hline 5 & Tokyo & 0.71 \\
\hline 6 & Singapore & 0.70 \\
\hline 7 & Moscow & 0.65 \\
\hline 8 & Shanghai & 0.64 \\
\hline 9 & Warsaw & 0.63 \\
\hline 10 & Sydney & 0.63 \\
\hline 11 & Brussels & 0.62 \\
\hline 12 & Buenos Aires & 0.62 \\
\hline 13 & Taipei & 0.61 \\
\hline 14 & Mumbai & 0.61 \\
\hline 15 & Toronto & 0.61 \\
\hline 16 & Athens & 0.60 \\
\hline 17 & Stockholm & 0.60 \\
\hline 18 & Beijing & 0.60 \\
\hline 19 & Bangkok & 0.60 \\
\hline 20 & Madrid & 0.60 \\
\hline 21 & Milan & 0.60 \\
\hline 22 & Seoul & 0.59 \\
\hline 23 & Budapest & 0.57 \\
\hline 24 & Vienna & 0.56 \\
\hline
\end{tabular}




$\begin{array}{lcc}25 & \text { Istanbul } & 0.56 \\ 26 & \text { Kuala Lumpur } & 0.55 \\ 27 & \text { Helsinki } & 0.55 \\ 28 & \text { Dubai } & 0.55 \\ 29 & \text { Lisbon } & 0.54 \\ 30 & \text { Mexico City } & 0.53 \\ 31 & \text { Amsterdam } & 0.53 \\ 32 & \text { Jeddah } & 0.53 \\ 33 & \text { Copenhagen } & 0.52 \\ 34 & \text { Bucharest } & 0.52 \\ 35 & \text { Chicago } & 0.51 \\ 36 & \text { Rome } & 0.51 \\ 37 & \text { Prague } & 0.50 \\ 38 & \text { Caracas } & 0.50\end{array}$


Table 13.2 Law network connectivity

$\begin{array}{ccc}\text { Rank } & \text { City } & \text { NC } \\ 1 & \text { London } & 1.00 \\ 2 & \text { New York } & 0.89 \\ 3 & \text { Paris } & 0.70 \\ 4 & \text { Frankfurt } & 0.59 \\ 5 & \text { Washington } & 0.58 \\ 6 & \text { Brussels } & 0.54 \\ 7 & \text { Hong Kong } & 0.53 \\ 8 & \text { Moscow } & 0.50\end{array}$


Table $13.3 \quad$ Financial network connectivity

\begin{tabular}{|c|c|c|}
\hline Rank & City & NC \\
\hline 1 & London & 1.00 \\
\hline 2 & New York & 0.96 \\
\hline 3 & Hong Kong & 0.93 \\
\hline 4 & Tokyo & 0.82 \\
\hline 5 & Singapore & 0.82 \\
\hline 6 & Paris & 0.79 \\
\hline 7 & Shanghai & 0.77 \\
\hline 8 & Sydney & 0.77 \\
\hline 9 & Seoul & 0.70 \\
\hline 10 & Madrid & 0.70 \\
\hline 11 & Milan & 0.70 \\
\hline 12 & Beijing & 0.69 \\
\hline 13 & Taipei & 0.64 \\
\hline 14 & Toronto & 0.64 \\
\hline 15 & Moscow & 0.61 \\
\hline 16 & Frankfurt & 0.61 \\
\hline 17 & Zurich & 0.60 \\
\hline 18 & Mumbai & 0.59 \\
\hline 19 & Brussels & 0.57 \\
\hline 20 & Kuala Lumpur & 0.57 \\
\hline 21 & Chicago & 0.56 \\
\hline 22 & Amsterdam & 0.56 \\
\hline 23 & Dublin & 0.56 \\
\hline
\end{tabular}


24

25

26

27

28
Jakarta $\quad 0.54$

Sao Paulo $\quad 0.54$

Bangkok $\quad 0.54$

Buenos Aires $\quad 0.51$

Warsaw $\quad 0.50$ 
Table 13.4 Accountancy network connectivity

\begin{tabular}{|c|c|c|}
\hline Rank & City & $\mathrm{NC}$ \\
\hline 1 & London & 1.00 \\
\hline 2 & New York & 0.79 \\
\hline 3 & Hong Kong & 0.74 \\
\hline 4 & Sydney & 0.69 \\
\hline 5 & Singapore & 0.67 \\
\hline 6 & Milan & 0.67 \\
\hline 7 & Paris & 0.66 \\
\hline 8 & Beijing & 0.64 \\
\hline 9 & Buenos Aires & 0.63 \\
\hline 10 & Kuala Lumpur & 0.62 \\
\hline 11 & Toronto & 0.61 \\
\hline 12 & Tel Aviv & 0.61 \\
\hline 13 & Tokyo & 0.60 \\
\hline 14 & Shanghai & 0.60 \\
\hline 15 & Jakarta & 0.60 \\
\hline 16 & Moscow & 0.60 \\
\hline 17 & Brussels & 0.59 \\
\hline 18 & Auckland & 0.59 \\
\hline 19 & Seoul & 0.59 \\
\hline 20 & Lisbon & 0.57 \\
\hline 21 & Rome & 0.57 \\
\hline 22 & Mumbai & 0.57 \\
\hline 23 & Mexico City & 0.57 \\
\hline 24 & Sao Paulo & 0.56 \\
\hline
\end{tabular}




\begin{tabular}{|c|c|c|}
\hline 25 & Berlin & 0.56 \\
\hline 26 & Madrid & 0.56 \\
\hline 27 & Istanbul & 0.56 \\
\hline 28 & Caracas & 0.56 \\
\hline 29 & Oslo & 0.55 \\
\hline 30 & New Delhi & 0.55 \\
\hline 31 & Kuwait & 0.55 \\
\hline 32 & Bogota & 0.55 \\
\hline 33 & Barcelona & 0.55 \\
\hline 34 & Vienna & 0.53 \\
\hline 35 & Jeddah & 0.52 \\
\hline 36 & Santiago & 0.52 \\
\hline 37 & Dublin & 0.52 \\
\hline 38 & Warsaw & 0.51 \\
\hline 39 & Guadalajara & 0.51 \\
\hline 40 & Riyadh & 0.50 \\
\hline 41 & Johannesburg & 0.50 \\
\hline 42 & Zurich & 0.50 \\
\hline 43 & Chicago & 0.50 \\
\hline 44 & Hamburg & 0.50 \\
\hline 45 & Athens & \\
\hline
\end{tabular}


Table 13.5 Management consultancy network connectivity

$\begin{array}{ccc}\text { Rank } & \text { City } & \text { NC } \\ 1 & \text { New York } & 1.00 \\ 2 & \text { London } & 0.67 \\ 3 & \text { Paris } & 0.65 \\ 4 & \text { Chicago } & 0.62 \\ 5 & \text { Hong Kong } & 0.61 \\ 6 & \text { Singapore } & 0.56 \\ 7 & \text { Tokyo } & 0.56 \\ 8 & \text { Zurich } & 0.55 \\ 9 & \text { Madrid } & 0.55 \\ 10 & \text { Beijing } & 0.53 \\ 11 & \text { Mumbai } & 0.50 \\ 12 & \text { Atlanta } & 0.50\end{array}$


Table 13.6 The globalizing effects of advanced producer service networks

\begin{tabular}{|c|c|c|c|c|}
\hline $\begin{array}{l}\text { Advanced producer } \\
\text { service network }\end{array}$ & $\begin{array}{l}\text { Number of } \\
\text { major cities }\end{array}$ & $\begin{array}{c}\% \text { old } \\
\text { 'first world' }\end{array}$ & $\begin{array}{c}\% \text { old 'second } \\
\text { world' }\end{array}$ & $\begin{array}{c}\% \text { old } \\
\text { 'third world' }\end{array}$ \\
\hline Advertising & 38 & 60.5 & 18.4 & 21.1 \\
\hline Law & 8 & 87.5 & 12.5 & 0.00 \\
\hline Financial services & 28 & 64.3 & 14.3 & 21.4 \\
\hline Accountancy & 45 & 57.8 & 8.9 & 33.3 \\
\hline $\begin{array}{l}\text { Management } \\
\text { Consultancy }\end{array}$ & 12 & 83.3 & 8.3 & 8.3 \\
\hline
\end{tabular}

